v. $12, n .6$

Vitória-ES, Nov.-Dec. 2015

p. 48 - 71 ISSN 1808-2386

\title{
Existing Relational Practice Between a Manufacturer and its Distributors and the Perception of the Relationship Value in the Dyad
}

\author{
Deonir De Toni ${ }^{\dagger}$ \\ Caxias do Sul University \\ Gabriel Sperandio Milan $^{\Omega}$ \\ Caxias do Sul University \\ Geverson Custódio Costa ${ }^{¥}$ \\ Caxias do Sul University \\ Fabiano Larentis ${ }^{ \pm}$ \\ Caxias do Sul University
}

\begin{abstract}
Inter-organizational relationships have attracted several studies in the relationship marketing area. Thus, the core objective of this work is to analyze what is the impact of relational practice in the manufacturer and distributor dyad on the perception of the relationship value. From the use of validated scales, a survey involving frontline staff (FS) of a manufacturer and its customers (distributors) was conducted, whereas the data analysis was done basically by the Structural Equation Modeling technique. The results confirmed the research hypotheses regarding the theoretical model tested, contributing to the assessment of the relationships in the dyad context. The evaluation of the two types of agents (manufacturer's and customers' FS) indicated differences of perception in the relationship, which may direct more assertive strategies and actions.
\end{abstract}

Keywords: Relationship marketing. Relationship value. Dyad.

Received: 11/02/2014; revised: 22/07/2014; accepted: 19/09/2014; divulged: 03/11/2015

*Author for correspondence

$\uparrow$. Doctor in Business Administration from the School of Management of the Federal University of Rio Grande do Sul

Type of contract: Graduate Program Professor in Business Administration from the University of Caxias do Sul Address: Rua Amadeu Zambon, Bento Gonçalves RS - Brazil - E-mail: dtoni2@ucs.br Telephone: (54) 3451-3260

\author{
${ }^{\Omega}$ Doctor in Production \\ Engineering in the Quality \\ Systems Area from the \\ Federal University of Rio \\ Grande do Sul \\ Type of contract: Professor, \\ University of Caxias do Sul \\ Address: Rua Francisco \\ Getúlio Vargas, Bloco F / \\ PPGA, Caxias do Sul - RS - \\ Brazil \\ E-mail: gsmilan@ucs.br \\ Telephone: (54) 3218.2100
}

$¥$ Master in Business Administration from the University of Caxias do Sul. Link: Business Consultant Address: Av. Presidente Kennedy, Carlos Barbosa RS - Brazil - E-mail: geverson.costa@yahoo.com.br Telephone: (54) 8117-5136

\author{
+ Doctor in Business \\ Administration from the School of \\ Management of the Federal \\ University of Rio Grande do Sul \\ Type of contract: Graduate \\ Program Professor in Business \\ Administration from the \\ University of Caxias do Sul \\ Address: Travessa \\ Montenegro,Bento Gonçalves - \\ RS - Brazil \\ E-mail: flarenti@ucs.br \\ Telephone: (54) 3055-2157
}




\section{INTRODUCTION}

he process of building long-term relationships is difficult to be reproduced. Generally, relationships established with the purpose of generating organizational, relational and informational resources can be transformed in a potential source of competitive advantage (MORGAN; HUNT, 1996; DYER; SINGH, 1998; ROWE; BARNES, 1998). For this reason, it is vital to understand the relationships as a competence that may establish a competitive differential for enterprises (DAY, 2000). The relations between suppliers and buyers evolve over time and are very dynamic, taking shape for various reasons and constituent dimensions, having a significant role in the performance of partners (PALMATIER et al., 2013; RIBEIRO; SILVA; PRADO, 2009).

Thus, this study has proposed to evaluate the dimensions (construct) intrinsic to existing relationships in a marketing channel, involving a manufactures and their customers (distributors). Consequently, the objective of the study was to verify what the impact of the relational practice in the manufacture and distributor dyad regarding perception of the relationship value. For this purpose, a theoretical model was proposed, based on the models by Wilson and Vloky (1997) and Vianna (1999) on which they underlie the relationship based on the level of investment, on the level of comparison of alternatives (suppliers/customers), in dependence, trust and commitment to the relationship. One of the contributions of this research to the models cited is the insertion of the relationship value construct as a dependent variable and the analysis of the relationship form the view point of the dyad.

There are few studies that approach relationship value from the perspective of specific value of the supplier and buyer dyad (ROCHA; LUCE, 2006). By assessing the perception of customers of a tool manufacturer for the construction industry and its frontline staff (FS), salesmen and sales representatives who attend these customers through personal sales, significant differences in the perception of the relationship between the parties were verified.

This research, therefore, contributes to the study of relational practice from the insertion of the perception of relationship value amongst those involve in a dyad. The theoretical model presented and the dyad analysis allowed us a better understanding of the existing relationships, which may permit a better alignment of strategies, actions and investments to strengthen the business relationship between the parties. 


\section{THEORETICAL FRAMEWORK}

\subsection{RELATIONSHIPS IN MARKETING CHANNELS}

A particular channel can be characterized by having a cooperative relationship among its members, collective goals, differentiation of duties, explicit rules and policies, structural complexity, communication and interdependence regarding duties performance and results. Marketing channel can be defined as a set of interdependent organizations involved in the process to provide a product and/or service for use or consumption, and the members of the channel can be manufactures, intermediaries (distributors) and end users (customers or consumers) (COUGHLAN et al., 2002).

The stimulus for the relational exchanges in marketing channels consists in the reduction of risks, uncertainties and in the possibility of obtaining competitive advantage, and the relational practice inherent in the channel can provide a competitive advantage in relation to other competitors (MACADAR, 2004). And the resulting relationships can impact positively on the distribution strategies of the channel members and act as a key factor in the performance of both (VARADARAJAN; JAYACHANDRAN, 1999; GULATI; SYTCH, 2007). This will enable a manufacturer, together with their intermediaries, lead customers to perceive positively the value of their offers in relation to their competitors, improving the quality of the relationship and the response time to customer (DYER, 1996; CHEN; PAULRAJ, 2004; ATHANASOPOULOU, 2009).

The relationships between the channel members have become fertile ground for the development of cooperative management capabilities, impacting the construction and maintenance of sustainable competitive advantages. There are evidences that positive relations between relationship dimensions (trust, commitment and cooperation) can foment such competitive advantages and business performance, inhibiting conflicts between exchange partners (LARENTIS; SLONGO, 2008, MILAN; DORION; MATOS, 2012).

Achrol, Reve and Stem (1983) address the dyadic relationships between members of a marketing channel and the environmental impacts where it operates a dyad of the relationship between the parties. Although authors recognize the importance of studying networks and not only dyads, they suggest the use of the dyad as the unit of analysis for their relevance and ease of operationalization. 


\subsection{RESEARCHED CONSTRUCTS AND HYPOTHESIS}

Several studies have been developed, demonstrating the effectiveness of relational practice, focusing on its fundaments (MORGAN; HUNT, 1994; HUNT; ARNETT; MADHAVARAN, 2006), its consequences (RAJAMMA; ZOLFAGHARIAN; PELTON, 2011; MILAN; DE TONI, 2012; PRIOR, 2012; MILAN et al., 2013) or development stages (DWYER; SCHURR; OH, 1987). Therefore, constructs relevant to the context of relationships to be studied were identified.

\subsubsection{Value and Investment in the Relationship}

Relationship value is a relevant construct, for it suggests a strong motivation for the parties involved to remain engaged in a future perspective (ULAGA; EGGERT, 2006; WALTER et al., 2003). Rust, Lemon and Zeithaml (2004) imply value as the support base of relationships between companies and their customers. In fact, some research has been done on applying the concept of value to assess entrepreneurial relations (HOGAN, 2001; WALTER; RITTER; GEMÜNDEN, 2001; ULAGA, 2001; ULAGA; EGGERT, 2006). The focus of this approach is to comprehend the way in which the parts of a business relationship perceive and interpret value, and how their perceptions affect their behavior (CORSARO; SNEHOTA, 2010).

According to Alejandro et al. (2011), the relationship value is a result of the product purchase process and/or services and the activities between suppliers and buyers. The benefits may vary, but they are distinct between elements of direct value (volume of purchases, profit and profitability) and elements of indirect value (innovation and market access) (RYSSEL; RITTER; GEMÜNDEN, 2004). According to Walter et al. (2003), the main objective of suppliers and customers engaged in a relationship should be to work together to generate mutual value that can be created offering benefits and reducing costs for both ambos (ULAGA; EGGERT, 2006).

Ribeiro, Silva and Prado (2009) indicate various levels of value ranging from a transactional value to the co-creation of value between companies. In order to reach a higher level of generating value, there must be a focus and alignment in-between the partners, which should be induced by a high level of development and relationship quality. Specific investments in the relationship are essential in the creation of value for partners (GHOSH; JOHN, 1999). Though, in the same way that they are valuable, they can lead to a relative vulnerability. These investments can characterize a dilemma for they present both a potential to promote as well as reducing the risk of an eventual opportunistic behavior (ROKKAN; 
HEIDE; WATHNE; BIONG; HEIDE, 2003). They are non-recoverable investments, since they cannot be recovered if the relationship comes to an end. Thus, the magnitude of investments may determine the choice of the relationship governance mechanisms, reinforcing or suppressing the importance of relational behavior between the parties (KOTHANDARAMAN; WILSON, 2000).

Investments in the relationship when viewed as reciprocal actions between the parties, may foment a positive atmosphere, remove uncertainties regarding risks and allow the relationship to develop and consolidate (SMITH; BARCLAY, 1997). However, the larger the magnitude, and the more specific investments these are, the more costly it will be to terminate the relationship and replace the partner, in view of the switching costs incurred, thus it would be more attractive and more rational, to invest in the maintenance of relationships (GANESAN, 1994; WATHNE; BIONG; HEIDE, 2001; DAGGER; DAVID, 2012). In this context, Heide and John (1988) express a positive relationship between the dependence and partners replacement costs (switch). It is proposed, therefore, the following hypothesis:

$\mathbf{H}_{1}$ : The investment in the relationship is positively related to the perception of dependence on the relationship.

\subsubsection{Alternative Providers (or Customers) Comparison Level}

The level of comparison of alternative suppliers/customers refers to the result quality (economic, technical and social) that can be obtained from the best alternative on the market (ANDERSON; NARUS, 1990). The alternative comparison level is also associated with the result that a potential supplier can provide the customer compared to the current supplier (WILSON, 1995). In case the comparison level of alternative suppliers is low, or nonexistent, the probability of the customer leaving the relationship will be lower (HOCUTT, 1998). If there are an expressive number of high quality alternative suppliers, enabling the idea of substitution, the dependency level is low, or lower (ANDERSON; NARUS, 1990), which would result in a level of commitment equally low to the supplier (HOCUTT, 1998).

The comparison level of alternative suppliers is directly related to the dependency between business partners (ANDERSON; NARUS, 1990), there being still a relation between the quality of the result inherent to the judgment of alternative supply and intensity of dependence in relation to one another. The inability of a buyer to find an alternative supplier, and if necessary, replacing them, can be considered an indicator of their dependence in relation to their current partner (KUMAR; SCHEER; STEENKAMP, 1995). And as such 
construct in a dyad will be studied, the reverse is true. Based on this, the following hypothesis is presented:

$\mathbf{H}_{2}$ : The alternative comparison level of suppliers/customers is positively related to dependence on the relationship.

\subsubsection{Dependence}

Dependence can be defined as the perceived difference between the dependence of a partner relative to one another in the context of relationship. The greater the relative dependence, the greater is the interest in maintaining the relationship (ANDERSON; NARUS, 1990).

Furthermore, the guidance for long-term relations between manufacturers and distributors, the mutual trust and the (inter) dependence play a paramount role in establishing this type of relationship. The dependence even when originating from investments in assets, e.g., in information systems is not enough for the development of a lasting relationship. Trust is necessary to shift the focus to future situations, cherishing the belief that when contingencies arise, the parties will share equitably and fairly the respective consequences (GANESAN, 1994).

The greater the level of dependence between the parties, the greater is the interest in sustaining the relationship under a long-term perspective, that is, the greater the work to preserve investments, the greater the resistance to short-term alternatives and a greater level of agreement with mutual actions of high risk, there being the incidence of commitment between the parties (ANDERSON; NARUS, 1990; SKINNER; GASSENHEIMER; KELLEY, 1992; MORGAN; HUNT, 1994; PALMATIER et al., 2013). Thus, it is suggested that:

$\mathbf{H}_{3}$ : Dependence on the relationship is positively related to the level of commitment among business partners

\subsubsection{Trust}

Trust is the conviction developed among business partners whereby expectations that the needs will be met in the long run by actions taken by the other party (ANDERSON; WEITZ, 1989). Therefore, trust is one of the most indicated constructs for any type of interaction to be based on or exchange process (MORGAN; HUNT, 1994; MILAN, 2004; GUNDLACH; ACHROL; MENTZER, 1995), it can be understood as a willingness to believe in a partner who conveys trust (MOORMAN; DESHPANDÉ; ZALTMAN, 1992), without 
any of the parties taking advantage of the vulnerabilities of the other (BARNEY; HANSEN, 1994; SHEPARD; SHERMAN, 1998).

Trust is an indicator of relational quality (GANESAN; HSS, 1997; BATT, 2001), improving performance when combined with formal aspects of a relationship (CANNON; ACHROL; GUNDLACH, 2000). However, there is a negative impact if one violates implicit or explicit standards (ROKKAN; HAUGLAND, 2002; LEE; PAE; WONG, 2001), affecting tangible or intangible results obtained by the parties, reducing existing levels of trust (DONEY; CANNON, 1997).

Just as it is for commitment, mutual trust is indispensable to consolidate relationships, due to the conviction related to the reliability and integrity perceived between partners (MORGAN; HUNT, 1994). Both constructs are considered as key factors, as they encourage managers to develop their activities in order to build relationships through cooperation (MORGAN; HUNT, 1994; PALMATIER et al., 2006; PALMATIER et al., 2013).

Ideally, trust should characterize an exchanging relationship between partners (LEE; PAE; WONG, 2001), whether it originates from the supplier or from the experience of the buyer (DONEY; CANNON, 1997). The influence that trust and commitment towards development and the outcomes of a relationship oppose the ideas of opportunism and of transactions costs minimization (BROWN; DEV; LEE, 2000).

Thereupon, we suggest the following hypothesis:

$\mathbf{H}_{4}$ : Trust is positively related to the commitment between business partners

\subsubsection{Commitment}

Amongst the constructs with the relationship scope, commitment is the most used in supplier-buyer relationships (WILSON, 1995). Commitment is the willingness to maintain a relationship steady, based on the goodwill to accept temporary sacrifices, in order to preserve the relationship (ANDERSON; WEITZ, 1989). It is the desire of a company to continue the relationship with another company, even if it takes sacrificing themselves to keep it (GEYSKENS; STEENKAMP; KUMAR, 1999).

For long term business relationships, commitment is a key factor of support, characterized by the belief developed by at least one partner that the relationship is so important that it justifies such great effort in order to keep such a relation (MORGAN; HUNT, 1994; PALMATIER et al., 2006; VASUDEVAN; GAUR; SHINDE, 2006; N'GOALA, 2007). 
As made noticeable, commitment represents one of the highest stages of relational bonding between the parties (DWYER; SCHURR; OH, 1987), bestowing a function of utmost importance with regards to the results from the perception of value in the relationship (FONTENOT et al., 1998; RYSSEL; RITTER; GEMÜNDEN, 2004). Thus, we propose the following hypothesis:

H5: The commitment to the relationship is positively related to the perceived value of the relationship.

In order to graphically represent the causal relationships proposed in Figure 1, the Theoretical Model is shown with the respective search hypotheses.

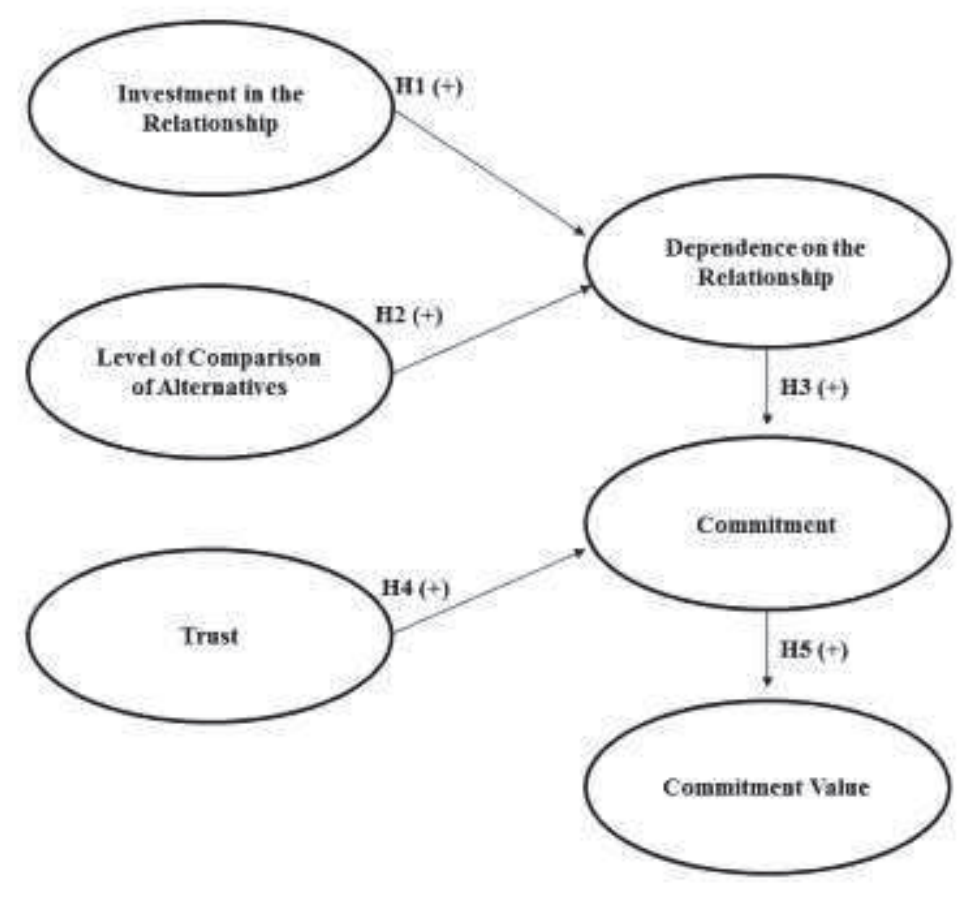

Figure 1 - Theoretical model and research hypotheses

Source: Developed with basis on Wilson and Vlosky (1997) and Vianna (1999).

\section{RESEARCH METHOD}

The present research is characterized as a quantitative research, of descriptive nature (HAIR JUNIOR et al., 2010; MALHOTRA; BIRKS; WILLS, 2012), implemented through a survey (FOWLER Jr., 2009; HAIR JUNIOR et al., 2010). For this purpose, the research was set in the context of a production chain of the building industry, involving a particular industry, in this study referred to as "manufacturer" and the building materials supplying trade for this industry represented by its wholesale customers, referred to as "distributors". The manufacturer is a company with national coverage that produces tools used only in the 
building sector, with its manufacturing unit located in the northeastern region of Rio Grande do Sul, occupying an area of $76000 \mathrm{~m}^{2}$.

The company employs 810 staff and its annual earnings in the domestic market is R \$ $300.000 .000,00$. Its main customers are wholesalers specialized in the distribution of products to stores serving the construction industry with materials, responsible for $60 \%$ of its earnings. The other $40 \%$ derive from direct sales to retailers, covering large stores: home centers and specialized stores.

The unit of analysis is the dyad, that is, the perception of customers' relationship with the supplier and the perception of suppliers' relationship with their customers. Thus, the informants for the customers were either buyers or owners who had a more direct relationship with the supplier. The informants for the supplier of each client were the frontline staff (FS), that is, representatives or salespeople who directly served these customers, since they are the ones keeping a more direct relationship with the customers, being the ones who may contribute to the perception of the relationship from the supplier's point perspective. For the target population, we considered all customers as "distributors" (410 companies) and the FS (58 field professionals, 15 salespeople and 43 sales representatives). Being that each FS evaluated up to three clients.

The data collection instrument (questionnaire) was developed from validated scales. For the constructs of investment in the relationship, level of comparison of alternative suppliers/customers dependence, trust and commitment, the scales by Wilson and Vlosky (1997) were adopted, translated and used by Vianna (1999), through the back translation method (DILLON; MADDEN; FIRTLE, 1994). The scale for the construct relationship value was developed from a study by Alejandro et al. (2011), which was based on Ulaga and Eggert (2006) and Ritter (2007), and with the back translation by Batista (2012). For these scales, five point agreement Likert-type scales were used (HAIR JUNIOR et al., 2010), ranging from "1. Totally disagree" to "5. Totally agree".

Two questionnaires were prepared. One for the customers and the other for the manufacture's FS. The questionnaires were adapted for each type of respondents, basically replacing the word "supplier" for "customer" in the case of FS and vice-versa. Both questionnaires went through content validation (HAIR JUNIOR et al., 2010; MALHOTRA; BIRKS; WILLS, 2012), being examined by three field experts (researching professors), having also performed a pre-test (FOWLWR JUNIOR, 2009) with field executives from the 
sales and marketing areas of the manufacturer, with some language changes being made to avoid eventual difficulties in the understanding of the respondents.

The questionnaires were coded by identifying the relationship in question, that is, the customer and the related FS had the same encoding, enabling the assessment only in cases containing answers from both parties. For the FS, the questionnaire mentioned the name of each client that should be evaluated. For customers the questionnaires were made standard since they would be assessing the same supplier.

In all, 820 questionnaires were sent, 410 being destined to customers and 410 to FS. In the end, 107 we evaluated 107 responses for customers and 107 for FS.

Data processing was done through the software IBM SPSS 18 and Amos 18, and the techniques used were the Exploratory Factor Analysis (EFA) and Confirmatory Factor Analysis (CFA) for the evaluation of the constructs and the Structural Equation Modeling to test relations (HAIR JUNIOR et al., 2009; BYRNE, 2010; KLINE, 2011). To meet the assumptions to apply these techniques we analyzed: missing data, having disposed of two customer's questionnaires in which these conditions took place; and univariate and multivariate outliers, having deleted thirteen cases with standardized values greater than $|3|$ (HAIR JUNIOR et al., 2009; ENDERS, 2010).

Multivariate techniques suppose that four assumptions should be met: normality, linearity homoscedasticity and multicollinearity (HAIR JUNIOR et al., 2009; KLINE, 2011). To assess normality, we used first of all the tests by Kolmogorov-Smirnov which point that all variables present significance $<0.05$, in this case, for this type of test the sample does not have a normal distribution. Thus, in order to test the univariate normality we also used the Skewness and Kurtosis values of asymmetry, and the multivariate normality test from tests by Mardia. The amplitude of the Skewness values ranged from -1.924 to the lowest value and 0.334 to the highest value, as for the Kurtosis amplitude, the lowest value was -1.432 and 3.355 for the highest value, in these tests the normality assumption was reached.

In view of the analysis of multivariate normality from Mardia's test, we observed that the estimated Kurtosis was 120.46 with a critical rate of 23.98. Thus, from the values in this magnitude it seems evident that the data present a moderate multivariate normality. However, despite the data not being approximately normal there is a reasonable consensus in the literature regarding the difficulties of obtaining normal data in empirical studies in social sciences (HAIR JUNIOR et al., 2009; BYRNE, 2009). 
Linearity and homoscedasticity can be evaluated from the bivariate scatterplots inspection, verifying the standardized residuals graph ( $Y=Z$ Zresid), with the dependent variable standardized ( $\mathrm{X}=\mathrm{Zpred}$ ) (straight regression line) and the graph $\mathrm{Y}=\mathrm{Zpred}$ and $\mathrm{X}=$ Dependent (oblique regression line) (PESTANA; GAGEIRO, 2005). All the dimensions of the model presented linear relations (in the analyzed variables, as $\mathrm{X}$ increased, $\mathrm{Y}$ also increased) and no curvilinear relationship emerged (quadratic or cubic curves) as recommended (KLINE, 2011).

For the analysis of multicollinearity, tests were carried out such as the Tolerance Value and the Variance Inflation Factor (VIF). The outcomes of the Tolerance Value identified that all variables have acceptable multicollinearity, that is, a tolerance between 0.427 to 0.933 , as well as the VIF with values ranging from 1.07 to 2.34 .

Before validating the integrated model, with all the covered constructs, individual validation of the constructs was carried out. For individual validation of the constructs convergent validity and discriminant validity of the same were assessed (HAIR JUNIOR et al., 2009; MALHOTRA; BIRKS; WILLS, 2012).

From the analysis of convergent validity of the constructs, all variables showed factor loadings higher than the minimum required (above 0.5). Regarding the variance extracted, only the construct alternative suppliers/customers comparison presented value lower than recommended $(0.50)$. For the reliability of the constructs, by calculating the comprised reliability, all the presented values were above the recommended (0.70) (HAIR JUNIOR et al., 2009).

For discriminant validity, we used the Fornell and Larcker test (1981). To apply it, a CFA by maximum likelihood was conducted for the constructs (BROWN; MOORE, 2012). Discriminant Validity is achieved when the extracted variance of each construct is greater than the variance shared (correlation squared) with other constructs (Table 1). We observed that the extracted variances of most of the constructs are larger than the shared variance. However the constructs dependence and investment in the relationship proved to be highly correlated. As there is a theoretical basis that sustains these two constructs (WILSON; VLOSKY, 1997, VIANNA, 1999), we decided to also perform the discriminant validity tests by Bagozzi and Phillips (1982). The results indicate that the constructs dependence and investment show significant differences in chi-square $(\mathrm{p}=0.000)$. Thus, form the test's results by Bagozzi and Phillips, we decided to consider the constructs in the theoretical model, converging with the work by Vianna (1999). 
Table 1 - Discriminant Validity of the Analyzed Constructs

\begin{tabular}{lccccc}
\hline \multicolumn{1}{c}{ Constructs } & Commitment & Trust & Dependence & Comparison & Investment \\
\hline Commitment & $\mathbf{0 , 6 2}$ & & & & \\
Trust & 0,48 & $\mathbf{0 , 6 3}$ & & & \\
Dependence & 0,33 & 0,27 & $\mathbf{0 , 6 0}$ & & \\
Comparison & 0,06 & 0,07 & 0,35 & $\mathbf{0 , 4 5}$ & $\mathbf{0 , 6 1}$ \\
Investment & 0,43 & 0,36 & 0,84 & 0,28 & \\
\hline
\end{tabular}

Note: The diagonal values indicate the variance extracted and the rest correspond to the shared variance.

\section{RESULTS AND DISCUSSION}

Out of the 214 answered questionnaires, 107 were customers' and 107 questionnaires were FSs'. Amongst the 107 clients, 75\% have related to the supplier for more than four years, $53 \%$ are in the Southeast region and $22 \%$ in the South region. Likewise, more than $75 \%$ of FS have related to these customers for more than 4 years. It is important to highlight that more than $70 \%$ of these customers are classified as A customers, considering the curve $\mathrm{A} / \mathrm{B} / \mathrm{C}$ by the representative criterion in the supplier's (manufacturer) revenue.

\subsection{PERCEPTIONS IN THE DYAD}

For investment in the relationship, there is a significant difference between the means $(p=0.006)$, presenting a mean of 3.18 in the perception of customer and 3.45 for the FS. A possible explanation is the difference in perception between the agents in relation to switching costs (changing) for an alternative supplier or customer. Regarding the comparison level of alternative supplier/customer, there is also a significant difference between the means ( $p$ $<0.05$ ), however, a reverse perception was observed. As customers identify that there are many alternative suppliers $($ mean $=3.27)$, the FS recognize that there are fewer options of alternative customers (mean $=2.95)$. Thus, we identified a stronger company's dependence relationship in relation to their clients, and on the other hand, customers have many options for purchase.

Dependence presented a significant difference $(p=0.000)$, with an average of 3.05 for customers' perception and 3.58 for FS. Thus, it is evident that the FS realize that they are more dependent on the relationship than customers are. This indicates that there is a gap of understanding between the participants of the dyad, which can cause an impact in the commitment between the parties, suggesting then that the manufacturer should invest more in the relationship in order to strengthen it.

Trust did not present significant differences among the means ( $>0.05)$, being the only construct from the ones surveyed with such condition taking place. We identified that $62 \%$ of the cases were in business relationships for longer than 5 years, indicating that a great number 
of the relationships represent mature relations, and that its duration is (longevity) is guided by a mutual trust based relationship. Commitment showed significant differences $(p=0.030)$, with a mean of 4.35 in the perception of customers and 4.54 for FS, suggesting that the supplier through the FS is more committed to the relationship when compared to customers. Finally, the value of the relationship showed significant differences between the means in the dyad $(\mathrm{p}=0.000)$, with a mean of 3.73 in the perception of customers and 4.10 for FS, showing an imbalance in the perception of value between the parties, and this aspect should be analyzed carefully among those involved in the relationship (supplier and customer).

\subsection{INDIVIDUAL VALIDATION OF CONSTRUCTS AND STRUCTURAL MODEL}

The validity of the measuring model depends on the quality of the indexes of adjustments, in other words, how well the model specified reproduces the covariance matrix between the indicators. First of all, we identified the quality of the indexes of adjustments of the constructs (Table 2).

Table 2 - Constructs' Adjustment Indexes

\begin{tabular}{c|c|c|c|c|c|c|c}
\hline Indexes & Criterion & Dependen & Compariso & Investment & Trust & Commitment & Value \\
\hline$\chi^{2} / g l(\mathrm{CMIN} / \mathrm{DF})$ & Up to 5 & 5,147 & 0,140 & 6,180 & 3,459 & 4,680 & 3,600 \\
\hline GFI & $\geq 0,9$ & 0,969 & 0,999 & 0,936 & 0,965 & 0,933 & 0,948 \\
\hline RMSEA & 0,00 a 0,10 & 0,140 & 0,000 & 0,156 & 0,100 & 0,130 & 0,110 \\
\hline TLI & $\geq 0,9$ & 0,941 & 1,020 & 0,900 & 0,949 & 0,944 & 0,953 \\
\hline CFI & $\geq 0,9$ & 0,961 & 1,000 & 0,915 & 0,958 & 0,966 & 0,962 \\
\hline
\end{tabular}

Note: (*) Hair Junior et al. (2009), Byrne (2010) and Kline (2011).

The analysis of the various indexes of adjustments of the constructs leads to the conclusion that in general, the quality of indexes is satisfactory and includes reference values (HAIR JUNIOR et al., 2009; BYRNE, 2010; KLINE, 2011). The investment construct was the only one to present $\chi^{2} / g l$ and RMSEA above the recommended, which does not invalidate the construct, but indicates that it should be analyzed and adjusted in their observable variables (indicators) for future research.

By analyzing the indexes of adjustments of the model (Table 3), we observed that the results were satisfactory and that in general, contemplate reference values. The values for $\chi^{2} / g l$, RMSEA, TLI and CFI are within the recommended. Only the GFI presented results close to the borderline levels (0.82). However, we can consider as a satisfactory adaptation in so far as more flexible values are accepted relating to the indexes of adjustment (e.g., GFI acceptance around 0.85) (KLINE, 2011). 
Table 3 - Indexes of Adjustments of the Structural Model

\begin{tabular}{c|c}
\hline Indexes of adjustments & Results \\
\hline$\chi^{2} / g l(\mathrm{CMIN} / \mathrm{DF})$ & 2,263 \\
\hline GFI & 0,820 \\
\hline RMSEA & 0,077 \\
\hline TLI & 0,900 \\
\hline CFI & 0,910 \\
\hline
\end{tabular}

\subsection{HYPOTHESIS TEST AND THE EXPLANATORY POWER OF THE MODEL}

A good adjustment of the model alone is not enough to support a structural theory, being necessary to verify the estimates the individual parametric estimates of each research hypothesis (LEE; CAI; MacCALLUM, 2012). Thus, we performed the hypothesis test, and the estimates were examined from the significance and magnitude of path coefficients (HAIR JUNIOR et al., 2009) (Table 4).

Table 4 - Hypothesis Test

\begin{tabular}{l|l|c|c|c|c}
\hline $\mathbf{H}_{\mathbf{i}}$ & \multicolumn{1}{|c|}{ Causal relationships } & C.R. $(\boldsymbol{\beta})$ & Error & Significance & Results \\
\hline $\mathbf{H}_{\mathbf{1}}$ & Investment $\rightarrow$ Dependence & 0,762 & 0,068 & $\mathrm{p}<0,001$ & Supported \\
\hline $\mathbf{H}_{\mathbf{2}}$ & Comparison $\rightarrow$ Dependence & $-0,224$ & 0,093 & $\mathrm{p}=0,016$ & Supported \\
\hline $\mathbf{H}_{\mathbf{3}}$ & Dependence $\rightarrow$ Commitment & 0,264 & 0,030 & $\mathrm{p}<0,001$ & Supported \\
\hline $\mathbf{H}_{\mathbf{4}}$ & Trust $\rightarrow$ Commitment & 0,455 & 0,055 & $\mathrm{p}<0,001$ & Supported \\
\hline $\mathbf{H}_{\mathbf{5}}$ & Commitment $\rightarrow$ Relationship Value & 1,371 & 0,118 & $\mathrm{p}<0,001$ & Supported \\
\hline
\end{tabular}

$\mathbf{H}_{1}(\beta=0.762, p<0.001)$ was supported, indicating that investment in the relationship has a positive influence on the perception of the relationship dependence. Therefore, increasing investments in the relationship by training the supplier, in assets for the customer sales force (distributor) and the allocation of resources for their exclusive use may influence their perception of dependence, discouraging switching to another supplier due to the switching costs.

$\mathbf{H}_{2}(\beta=-0.224, p=0.016)$ was supported suggesting that the comparison level of alternative supplier/customer has an influence on the perception of dependence in the relationship. A differentiation strategy by the manufacturer could reduce the alternatives of high-level suppliers, and the more valued this differential is, more unlikely the customer will tend to switch suppliers, contributing to a sense of dependence on the current supplier.

$\mathbf{H}_{3}(\beta=0.264, p<0.001)$ was supported revealing that dependence on the relationship influences the commitment between business partners. The feeling of dependence, coming from investments in the relationship can result in a sense of mutual commitment, even in the short term. The dependence generated by the lack of alternatives due to a comparative and competitive advantage from one party in relation to the other in the dyad may generate indeed a long term commitment. It is important to point out that in the model proposed by Vianna 
(1999) this hypothesis was not confirmed, which can be configured as a relevant contribution from this research.

$\mathbf{H}_{4}(\beta=0.455, \mathrm{p}<0.001)$ was supported, indicating that trust is positively related to the level of commitment between business partners. The existence of trust presupposes the mutual belief of honesty and benevolence between the parties involved in the relationship, increasing the willingness of participants in the dyad to share information, and to want consciously and deliberately to remain trading with one another in a continuous and long-term perspective. Hence, the security to invest in the relationship would increase, reducing eventual opportunistic behavior, contributing to a greater relational engagement and joint efforts by the partners, further enhancing the commitment and the existing trust.

$\mathbf{H}_{5}(\beta=1.371, \mathrm{p}<0.001)$ was also supported, elucidating that the commitment positively influences the value of the relationship, from the view point of the dyad. A relationship guided in generating mutual value that can be created offering benefits and reducing costs for both partners, causing the dyad actors to commit themselves to work together in order to gather results from this relationship, providing greater perceived value of the relationship.

Therefore, figure 2 presents the effects of path analysis identifying the impacts of the various constructs on the value of the relationship. The results show that all paths have a significant impact on the variables listed in the proposed model.

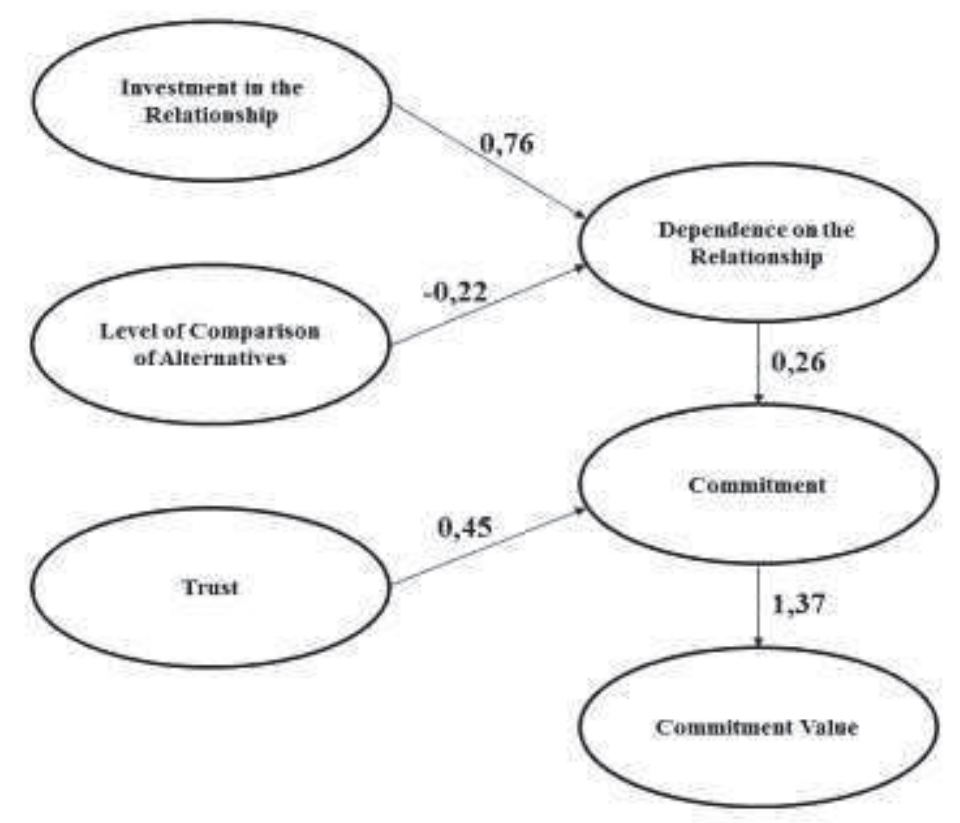

Figure 2 - Theoretical model and the effects of the path analysis 
Here are also presented the determination coefficients $\left(\mathrm{R}^{2}\right)$ of the theoretical model (Table 5), calculated by multiple correlations to the square of each dependent variable (HAIR JUNIOR et al., 2009). The $\mathrm{R}^{2}$ s are useful to determine the relative importance of each one of the tested causal relations, representing the combined effect of the independent variables on the dependent variables, indicating the proportion of variance of the dependent variable that is explained by the independent variables (HAIR JUNIOR et al., 2009).

Table 5 - Determination Coefficients of the Model

\begin{tabular}{c|c}
\hline Dependent Variables & Determination Coefficients $\left.\mathbf{( R}^{\mathbf{2}}\right)$ \\
\hline Dependence & 0,752 \\
\hline Commitment & 0,845 \\
\hline Relationship Value & 0,892 \\
\hline
\end{tabular}

The results of the research identified a high explanatory power of the model and its causal relations associated to the perception of relationship value existing in the dyads, by the following results: $89.20 \%$ of the relationship value (perceived) are explained by their independent variables, in this case commitment between business partners, trust, dependence on the relationship, alternative suppliers/customers comparison and investment in the relationship; $84.50 \%$ of the commitment between business partners are explained by trust, dependence on the relationship, alternative suppliers/customers comparison and the investment in the relationship; $75.20 \%$ of dependence on the relationship are explained by alternative suppliers/customers comparison and investments in the relationship.

\subsection{VARIABLE MODERATOR EFFECTS}

In order to assess how much the difference of the perception of the "types of agents" in the dyad, in this case customers (distributors) and the FS, moderates the relationship between the constructs, we proceeded to the multigroup analysis, following the recommended procedures (BYRNE, 2010). Sobel (1982) indicates that when a score-z is higher than \pm 1.96 , $\mathrm{p}<0.05$, the same shall certify that the indirect effect is non-zero, indicating an influence of the variable. Table 6 shows the results and the differences between the two types of surveyed agents.

Table 6 - Variable Moderator Effects

\begin{tabular}{|c|c|c|c|c|c|c|c|}
\hline \multirow{2}{*}{ Causal Relations } & \multicolumn{2}{|c|}{ Customers } & \multicolumn{2}{|c|}{ FS } & \multirow{2}{*}{ Score-z } & \multirow{2}{*}{ P-Value } & \multirow{2}{*}{ Results } \\
\hline & C.R. ( $\beta$ ) & $\mathbf{p}$ & C.R. ( $\beta$ & $\mathbf{P}$ & & & \\
\hline Investment $\rightarrow$ Dependence & 0,592 & 0,000 & 0,743 & 0,000 & 1,193 & $p>0,05$ & Not significant \\
\hline Comparison $\rightarrow$ Dependence & 0,186 & 0,216 & $-0,363$ & 0,000 & 2,479 & $\mathrm{P}<0,05$ & Significant \\
\hline Dependence $\rightarrow$ Commitment & 0,316 & 0,000 & 0,238 & 0,000 & $-1,061$ & $\mathrm{p}>0,05$ & Not significant \\
\hline Trust $\rightarrow$ Commitment & 0,703 & 0,000 & 0,278 & 0,000 & $-3,731$ & $\mathrm{P}<0,05$ & Significant \\
\hline Commitment $\rightarrow$ Relationship Value & 1,296 & 0,000 & 1,506 & 0,000 & 0,714 & $\mathrm{p}>0,05$ & Not significant \\
\hline
\end{tabular}


Only two constructs showed significant differences in its causal constructs between the participants of the dyad $(\mathrm{p}<0.001)$, since the relation between comparison of alternatives and the dependence in the relationships is stronger in the perception of the FS $(\beta=-0.363)$ than what it is for customers $(\beta=0.186)$. In addition, for the FS there is a greater perception of dependence on the relationship (mean $=2.95$ ), given that they observe more the possibility of alternative suppliers (mean $=3.27$ ). Such observation can justify why the relationship between the comparison of suppliers/customers alternative and the dependence on the relationship is stronger in the view of the FS. The relationship between trust and commitment showed an inverse situation, because the relationship is stronger in the perception of customers $(\beta=0.703)$ than it is for the FS $(\beta=0.278)$. This suggests that the greater the trust the greater the probability of there being a commitment. It is possible to infer that a greater level of trust from the customers in relation to the supplier contributes to generate a greater commitment from the customers in relation to the latter.

\section{FINAL CONSIDERATIONS}

The theoretical implications of this study seek to contribute to a greater knowledge of relational practice, in which we can highlight three contributions. First of all, it is possible to certify both in relation to the indexes of adjustment of the tested model, as well as the hypothesis test, which the model demonstrated it to be valid, bringing new empirical evidences inherent to the tested models by Wilson and Vlosky (1997) and Vianna (1999).

The second contribution is in the incorporation of the relationship value. By validating an alternative model, adapted to the cited models, considering such construct, we sought a contribution through a new perspective to assess the relationship as dyads, given that the relationship value entails on the perception of the generated benefits to the business partner. The results on relationship value are recent, there being few applied studies and empirical evidences (ROCHA; LUCE, 2006). The value of the relationship is a result of the process of relations involving a dyad, which, based on the perceived benefits and costs increase mutual commitment and the satisfaction of partners (ALEJANDRO et al., 2011). The main objective of engaging suppliers and customers in close and lasting relationships should be to cooperate, to work together to generate mutual value, which can be created by offering benefits and reducing costs for both partners (ULAGA; EGGERT, 2006).

The third contribution is related to adding to the few existing studies on the theme, the perspective of the dyad in a marketing channel. The dyad even with its importance being recognized by various studies linked to relational practices, though not explored very much 
yet (LARENTIS, 2010; ROCHA; LUCE, 2006; SMITH, 1998), provides a convenient borderline to examine the nature of the phenomenon in question, since the basic unit of relationship analysis between buyer and seller implies the interaction between them, i.e. in the dyad (ACHROL; REVE; STERN, 1983).

The dyad evaluation is considered a multigroup analysis, with the moderator variable "types of agent", enabled to identify significant differences on relations between the constructs comparison level of alternative supplier/customer and the dependence on the relationship and between trust and commitment.

Such research findings reinforce the statement that studies on the dyad's perspective can bring robust evidence of how constructs can relate differently in the perception of partners. And these contributions can assist in targeting strategies and actions that manufacturers can implement to strengthen existing relationships with customers (distributors) in a marketing channel.

\section{REFERENCES}

ACHROL, R.S.; REVE, T.; STERN, L.W. The environment of marketing channel dyads: a framework for comparative analysis. Journal of Marketing, v. 47, n. 4, p. 55-67, 1983.

ALEJANDRO, T.B. et al. The outcome of company and account manager relationship quality on loyalty, relationship value and performance. Industrial Marketing Management, v. 40, n. 1, p. 36-43, 2011.

ANDERSON, E.; WEITZ, B. A. Determinants of continuity in conventional industrial channel dyads. Marketing Science, v. 8, n. 4, p. 310-323, 1989.

ANDERSON, J. C.; NARUS, J. A. A model of distributor firm and manufacturer firm working partnerships. Journal of Marketing, v. 54, n. 1, p. 42-58, 1990.

ATHANASOPOULOU, P. Relationship quality: a critical literature review and research agenda. European Journal of Marketing, v. 43, n. 5/6, p. 583-610, 2009.

BAGOZZI, R. P.; PHILLIPS, L. W. Representing and testing organizational theories: a holistic construal. Administrative Science Quarterly, v. 27, p. 459-489, 1982.

BARNEY, J. E. G.; HANSEN, M. H. Trustworthiness as a source of competitive advantage. Strategic Management Journal, v. 15, n. 8, p. 175-190, 1994.

BATISTA, G. H. Percepção do cliente sobre a manutenção do relacionamento com fornecedores preferenciais de TI. 2012. 178 f. Dissertação (Mestrado em Administração) Universidade do Valoe do Rio dos Sinos (UNISINOS), São Leopoldo (RS), 2012.

BATT, P. J. Relational quality: further evidence of a single higher order construct in industrial market. In: ANNUAL INDUSTRIAL MARKETING AND PURCHASING 
CONFERENCE INTERACTIONS, RELATIONSHIPS \& NETWORKS: STRATEGIC DIMENSIONS, 17., 2001, Oslo (NOR). Anais... Oslo: IMP Group, 2001.

BROWN, J. R.; DEV, C. S.; LEE, D. Managing marketing channel opportunism: the efficacy of alternative governance mechanisms. Journal of Marketing, v. 64, n. 2, p. 51-65, 2000.

BROWN, T. A.; MOORE, M. T. Confirmatory factor analisys. In: HOYLE, R.H. (Ed.). Structural equation modeling. New York: Guilford Press, 2012. cap. 22, p. 361-379.

BYRNE, B. M. Structural equation modeling with AMOS: basic concepts, applications, and programming. 2. ed. New York: Taylor \& Francis Group, 2010.

CANNON, J. P.; ACHROL, R. S.; GUNDLACH, G. T. Contracts, norms and plural from governance. Academy of Marketing Science, v. 8, n. 2, p. 180-195, 2000.

CHEN, I. J.; PAULRAJ, A. Understanding supply chain management: critical research and a theoretical framework. International Journal of Production Research, v. 42, n. 1, p. 131$163,2004$.

CORSARO, D.; SNEHOTA, I. Searching for relationship value in business markets: are we missing something? Industrial Marketing Management, v. 39, n. 6, p. 986-995, 2010.

COUGHLAN, A. T. et al. Canais de marketing e distribuição. 6. ed. Porto Alegre: Bookman, 2002.

DAGGER, T.S.; DAVID, M.E. Uncovering the real effect of switching costs on the satisfaction-loyalty association: the critical role of involvement and relationship benefits. European Journal of Marketing, v.36, n.3/4, p.447-468, 2012.

DILLON, W.R.; MADDEN, T.J.; FIRTLE, N.H. Marketing research in a marketing environment. St. Louis: Times Mirror, 1994.

DAY, G.S. Managing marketing relationship. Journal of the Academy of Marketing Science, v.28, p.24-30, 2000.

DONEY, P.M.; CANNON, J.P. An examination of the nature of trust in buyer-seller relationships. Journal of Marketing, v.61, n.2, p.35-51, 1997.

DWYER, R.; SCHURR, P.; OH, S. Developing buyer-seller relationships. Journal of Marketing, v.51, n.2, p.11-27, 1987.

DYER, J.H. Does governance matter? Keiretsu alliances and asset specificity as sources of Japanese competitive advantage. Organization Science, v.7, n.6, p.649-666, 1996.

DYER, J.H.; SINGH, H. The relational view: cooperative strategy and sources of interorganizational competitive advantage. Academy of Management Review, v.24, n.4, p.660679, 1998.

ENDERS, C.K. Applied missing data analysis. New York: Gilford Press, 2010. 
FONTENOT, R. et al. Effect of buyer-seller relationship structure on firm performance. In: AMERICAN MARKETING ASSOCIATION (AMA), 1998, Austin (TEX). Anais... Austin: AMA, 1998.

FORNELL, C.; LARCKER, D.F. Evaluating structural equation models with unobservable variables and measurement error: algebra and statistics. Journal of Marketing, v.18, n.1, p.39-59, 1981.

FOWLER JUNIOR, F.J. Survey research methods. 4. ed. Thousand Oaks: Sage, 2009.

GANESAN, S. Determinants of long-term orientation in buyer-seller relationship. Journal of Marketing, v.58, n.2, p.1-19, 1994.

GANESAN, S.; HESS, R. Dimensions and levels of trust: implications for commitment to a relationship. Marketing Letters, v.8, n.4, p.439-448, 1997.

GEYSKENS, I.; STEENKAMP, J.B.E.M.; KUMAR, N. A meta-analysis of satisfaction in marketing channel relationships. Journal of Marketing Research, v.36, n.2, p.223-238, 1999.

GHOSH, M.; JOHN, G. Governance value analysis and marketing strategy. Journal of Marketing, v.63, n.4, p.131-145, 1999.

GULATI, R.; SYTCH, M. Dependence asymmetry and joint dependence in interorganizational relationships: effects of embeddedness on a manufacturer's performance in procurement relationships. Administrative Science Quarterly, v.52, n.1, p.32-69, 2007.

GUNDLACH, G.T.; ACHROL, R.S.; MENTZER, J.T. The structure of commitment in exchange. Journal of Marketing, v.59, n. 1, p.78-92, 1995.

HAIR JUNIOR, J.F. et al. Análise multivariada de dados. 6.ed. Porto Alegre: Bookman, 2009.

et al. Fundamentos de pesquisa de marketing. Porto Alegre: Bookman, 2010.

HEIDE, J.B.; JOHN, G. The role of dependence balancing in safeguarding transactionspecific assets in conventional channels. Journal of Marketing Research, v.46, n.52, p.20$35,1988$.

HOCUTT, M.A. Relationship disolution model: antecedents of relationship commitment and the likelihood of dissolving a relationship. Internation Journal of Service Industry Management, v.9, n.2, p.189-200, 1998.

HOGAN, J.E. Expected relationship value. Industrial Marketing Management, v.30, n.4, p.339-351, 2001.

HUNT, S.D.; ARNETT, D.B.; MADHAVARAN, S. The explanatory foundations of relationship marketing theory. Journal of Business \& Industrial Marketing, v.21, n.2, p.7287, 2006.

JOHNSON, R.A.; WICKERN, D.W. Applied multivariate statistical analysis. 6. ed. Upper Saddle River: Pearson/Prentice Hall, 2007. 
KLINE, R.B. Principles and practice of structural equation modeling. 3. ed. New York: Gilford Press, 2011.

KOTHANDARAMAN, P.; WILSON, D.T. Implementing relationship strategy. Industrial Marketing Management, v.29, n.4, p.339-349, 2000.

KUMAR, N.; SCHEER, L.K.; STEENKAMP, J.E.M. The effect of perceived interdependence on dealer attitudes. Journal of Marketing Research, v.32, n.3, p.348-356, 1995.

LARENTIS, F.; SLONGO, L. A. Relacionamento em canais de marketing como fonte de vantagem competitiva sustentável. R. Adm. São Paulo, v.43, n.3, p.209-223, jul./ago./set. 2008 .

LARENTIS, F. Marketing de relacionamento e cultura organizacional: uma perspectiva interorganizacional. 2010. Tese (Doutorado em Administração) - Universidade Federal do Rio Grande do Sul (UFRGS), Porto Alegre (RS), 2010.

LEE, D.; PAE, J.H.; WONG, Y.H. A model of close business relationships in China (Guanxi). European Journal of Marketing, v.35, n.1/2, p.51-69, 2001.

LEE, T.; CAI, L.; MacCALLUM, R.C. Power analisys for tests of structural equation modeling. In: HOYLE, R.H. (Ed.). Structural equation modeling. New York: Guilford Press, 2012. cap.11, p.181-194.

MACADAR, B.M. Pode o marketing de relacionamento gerar vantagem competitiva? In: SLONGO, L.A.; LIBERALI, G. (Org.). Marketing de relacionamento: estudos, cases e proposições de pesquisa. São Paulo: Atlas, 2004. cap.10, p.153-162.

MALHOTRA, N.K.; BIRKS, D.; WILLS, P. Marketing research: applied approach. 4. ed. New York: Pearson, 2012.

MILAN, G.S. A retenção de clientes como resultado da prática do marketing de relacionamento. In: MILAN, G.S.; BRANCHI, N.V.L. (Org.). Administração mercadológica: teoria e pesquisas. Caxias do Sul: EDUCS, 2004. v. 1. cap.8, p.177-195.

MILAN, G.S. et al. The relational practice existing between a service provider and its customers and the customer retention: a comparison between a theoretical model and rival. Australian Journal of Basic and Applied Sciences, v.7, n.7, p.904-915, 2013.

MILAN, G.S.; DE TONI, D. A construção de um modelo sobre a retenção de clientes e seus antecedentes em um ambiente de serviços. Revista Eletrônica da Administração, v.18, n.2, p.433-467, 2012.

MILAN, G.S.; DORION, E.; MATOS, J.A.R. Distribution channel conflict management: a Brazilian experience. Benchmarking: An International Journal, v.19, n.1, p.32-51, 2012.

MOORMAN, C.; DESHPANDÉ, R.; ZALTMAN, G. Relationships between providers and users of market research: the dynamics of trust within and between organizations. Journal of Marketing Research, v.29, n.3, p.314-328, 1992. 
MORGAN, R.M.; HUNT, S.D. The commitment-trust theory of relationship marketing. Journal of Marketing, v.58, n.3, p.20-38, 1994.

;. Relationship-based competitive advantage: the role of relationship marketing in marketing strategy. Working Paper. The University of Alabama, 1996.

MULAIK, S.A. Foundations of factor analysis. 2. ed. Boca Raton: Taylor \& Francis Group, 2010.

N'GOALA, G. Customer switching resistance (CSR): the effects of perceived equity, trust and relationship commitment. International Journal of Service Industry Management, v.18, n.5, p.510-533, 2007.

PALMATIER, R.W. et al. Factors influencing the effetiveness of relationship marketing: a meta-analysis. Jornal of Marketing, v.70, n.4, p.136-153, 2006.

. et al. Relationship velocity: toward a theory of relationship dynamics. Journal of Marketing, v.77, n.1, p.13-30, 2013.

PESTANA, M.H.; GAGEIRO, J.N. Análise de dados para ciências sociais: a complementariedade do SPSS. Lisboa: Sílabo, 2005.

PRIOR, D.D. The effects of buyer-supplier relationships on buyer competitiveness. Journal of Business \& Industrial Marketing, v.27, n.2, p.100-114, 2012.

RAJAMMA, R.K.; ZOLFAGHARIAN, M.A.; PELTON, L.E. Dimension and outcomes of B2B relational exchange: a meta-analysis. Journal of Business \& Industrial Marketing, v.26, n.2, p.104-114, 2011.

RIBEIRO, C.M.; SILVA, C.L.M.; PRADO, P.H.M. Aspectos intervenientes das relações interorganizacionais entre indústrias fornecedoras e uma rede de varejo do segmento alimentício. In: SIMPOI, 12., 2009, São Paulo (SP). Anais... São Paulo: FGV, 2009.

RITTER, T. A framework for analyzing relationship governance. Journal of Business \& Industrial Marketing, v.22, n.3, p.196-201, 2007.

ROCHA, A.D.; LUCE, F.B. Relacionamentos entre compradores e vendedores: origens e perspectivas no marketing de relacionamento. Revista de Administração de Empresas, v.46, n.3, p.87-93, 2006.

ROKKAN, A.I.; HAUGLAND, S.A. Developing relational exchange: effectiveness and power. European Journal of Marketing, v.36, n.1, p.211-230, 2002.

ROKKAN, A.I.; HEIDE, J.B.; WATHNE, K.H. Specific investments in marketing relationships: expropriation and bonding effects. Journal of Marketing Research, v.40, n.2, p.210-224, 2003.

ROWE, W.G.; BARNES, J.G. Relationship marketing and sustained competitive advantage. Journal of Market Focused Management, v.2, n.3, p.67-85, 1998.

RUST, R.T.; LEMON, K.N.; ZEITHAML, V.A. Return on marketing: using customer equity to focus marketing strategy. Journal of Marketing, v.68, n.1, p.109-127, 2004. 
RYSSEL, R.;. RITTER, T.; GEMÜNDEN, H.G. The impact of information technology deployment on trust, commitment and value creation in business relationships. Journal of Business \& Industrial Marketing, v.19, n.3, p.197-207, 2004.

SHEPPARD, B.; SHERMAN, D.M. The grammars of trust: a model and general implications. Academy of Management Review, v.23, n.3, p.422-437, 1998.

SKINNER, S.J.; GASSENHEIMER, J.B.; KELLEY, S.W. Cooperation in supplier-dealer relations. Journal of Retailing, v.68, n.2, p.174-193, 1992.

SMITH, J.B. Buyer-seller relationships: similarity, relationship managements, and quality. Psychology \& Marketing, v.15, n.1, p.3-21, 1998.

SMITH, J.B.; BARCLAY, D.W. The effects of organizational differences and trust on the effectiveness of selling partner relationships. Journal of Marketing, v.61, n. 1, p.3-21, 1997.

SOBEL, M. Asymptotic intervals for indirect effects in structural equations models. In: LEINHART, S. (Ed.). Sociological methodology. San Francisco: Jossey-Bass, 1982. p.290-312.

ULAGA, W. Customer value in business markets. Industrial Marketing Management, v.30, n.4, p.315-319, 2001.

ULAGA, W.; EGGERT, A. Relationship value and relationship quality. European Journal of Marketing, v.40, n.3/4, p.311-327, 2006.

VARADARAJAN, P.R.; JAYACHANDRAN, S. Marketing strategy: an assessment of the state of the field and outlook. Journal of the Academy of Marketing Science, v.27, n.2, p.120-143, 1999.

VASUDEVAN, H.; GAUR, S.S.; SHINDE, R.K. Relational switching costs, satisfaction and commitment: a study in the Indian manufacturing context. Asia Pacific Journal of Marketing and Logistics, v.18 n.4, p.342-353, 2006.

VIANNA, D. A. A proposição de um modelo sobre marketing de relacionamento no contexto business-to-business: avaliação inicial na indústria metalmecânica do Rio Grande do Sul. 1999. Dissertação (Mestrado em Administração de Empresas) - Universidade Federal do Rio Grande do Sul (UFRGS), Porto Alegre (RS), 1999.

WALTER, A. et al. Functions of industrial supplier relationships and their impact on relationship quality. Industrial Marketing Management, v.32, n.2, p.159-169, 2003.

WALTER, A.; RITTER, T.; GEMÜNDEN, H.G. Value creation in buyer-seller relationships: theoretical considerations and empirical results from a supplier's perspective. Industrial Marketing Management, v.30, n.4, p.365-377, 2001.

WATHNE, K.H.; BIONG, H.; HEIDE, J.B. Choice of supplier in embedded markets: relationship and marketing program effects. Journal of Marketing, v.65, n.2, p.54-66, 2001.

WILSON, D. An integrated model of buyer-seller relationships. Journal of the Academy of Marketing Science, v.23, n.4, p.335-346, 1995. 
WILSON, E.; VLOSKY, R. Partnering relationship activities: building theory from case study research. Journal of Business Research, v.39, n.1, p.59-70, 1997. 